\title{
Effectiveness of Bacillus subtilis (Vitafort) probiotic used for raising broiler chickens
}

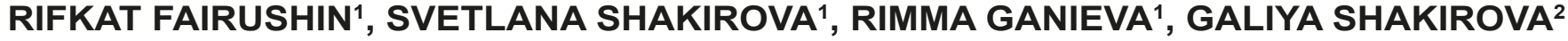 \\ ${ }^{1}$ Department of Morphology, Pathology, Pharmacy and Non-Infectious Diseases, \\ Federal State Budgetary Educational Establishment of Higher Education "Bashkir State Agrarian University", \\ 50-letia Octyabrya str., 34, Ufa, 450001, Russian Federation \\ ${ }^{2}$ Department of Anatomy and Histology, Skryabin Moscow State Academy of Veterinary Medicine and Biotechnology, \\ Akademika K.I. Skryabina str., 23, Moscow, 109472, Russian Federation
}

Fairushin R., Shakirova S., Ganieva R., Shakirova G. Effectiveness of Bacillus subtilis (Vitafort) probiotic used for raising broiler chickens

Summary

Unbalanced nutrition as well as diseases of infectious and non-infectious etiology lead to a decrease in production and a significant loss of farm animals and birds. To mitigate these problems, various probiotic drugs (probiotics) are introduced into the diets of birds and animals for preventive purposes. The aim of the research was to study the effect of the Vitafort probiotic, containing antagonistic bacteria of the endophytic strain Bacillus subtilis B11, on the body of broiler chickens. The effect of Vitafort was assessed by measuring the live weight and average daily growth of birds. In addition, a morphological study of blood was carried out and the content of Bacillus subtilis in the small intestine was determined. It was found that the endophytic strain Bacillus subtilis B11 improved the intestinal microflora. Thus, on day 5 of its use, the number of microorganisms varied from $4.1 \times 10^{4}$ to $8.2 \times 10^{4} \mathrm{CFU} / \mathrm{g}$, and on day 42 the same number varied from $4 \times 10^{8}$ to $5.8 \times 10^{8} \mathrm{CFU} / \mathrm{g}$ on day 42, the contents of red blood cells, haemoglobin, and white blood cells in the blood of chickens from the experimental group were higher by $6.44 \%, 3.44 \%$, and $2.11 \%$, respectively, than they were in the control group. Considering the above facts, it can be assumed that the absorption of nutrients in the intestine improved, and metabolic processes were activated due to an increase in the transport abilities of red blood cells.

Keywords: chickens, probiotics, Vitafort, blood, small intestine

One of the priority tasks of animal husbandry is to provide the population of the Russian Federation with products of animal origin. In terms of weight, poultry meat is among the most important types of meat produced in the Russian Federation (7). According to FAS USDA, in 2021, the Russian Federation will produce 4,725 million tons of broiler meat. In order to provide the population with poultry meat, adjustments are made to animal breeding and the conditions of animal maintenance and feeding (40). But the acceleration of the maturation and growth of birds $(32,33)$ is accompanied by various diseases, such as heart hypertrophy, dyschondroplasia of the tibial ankle joint (running) bone, and ascites. All this results in a significant loss of birds $(2,6,14,34)$. Moreover, the quality of the resulting meat products is also reduced, since the fat content of bird carcasses increases (15).

One of the most important factors in raising animals and poultry is a well-designed feeding diet suited to the characteristics of the given species (16). A welldesigned diet makes it possible to maximize animals' inherent qualities and adapt the body to different environmental conditions (30). Feed additives and various Bacillus subtilis are introduced into the diet to enrich it with minerals and vitamins and increase the feed palatability (38). Therefore, the probiotic Vitafort (12), probiotic Prolam (8), probiotic lactobacilli $(22,25)$, preparations of the Vetom series (35), bee products (36), biologics (16), nano-and microparticles of copper (24), and feed made from sturgeon (4) are introduced into the diet of animals and birds to increase the digestibility and use of the nutrients of mixed feed.

Probiotics include non-pathogenic microorganisms that affect the body's microflora and suppress pathogenic microorganisms $(1,3,10,13,41)$. Anaerobic spore-forming rod-shaped bacteria of the genus Bacillus produce about 200 antibiotics, about 70 of which are $B$. subtilis. Preparations based on $B$. subtilis increase the digestibility of feed. They have a beneficial effect on the microflora of the gastrointestinal tract (26, 29) and the histological structure of the wall of various parts of the intestine (9). They also prevent dysbiosis, 
stimulate the immune response of the body $(17,19$, $21,39)$ and its adaptive properties. As a result, diseases of the gastrointestinal tract are either completely prevented or have a milder and shorter course $(8,25)$. In some cases, antibiotics are not necessary (28). Probiotics have a more pronounced effect on young animals, which are germ-free. In their case, microbial colonization of the gastrointestinal tract by microflora, including pathogenic organisms, occurs faster (18-20).

Probiotics normalize the intestinal microflora and have additional positive metabolic and immunological effects. In addition, they possess anti-inflammatory properties and stimulate local immunoprotection (27).

In connection with the above, this study aimed to investigate the effect of the local probiotic Vitafort, produced from antagonistic bacteria of the endophytic strain Bacillus subtilis B11, on the body of broiler chickens.

\section{Material and methods}

The study site. The research was carried out at a poultry farm owned by the open joint-stock company Turbaslinsky Broiler, located in the Blagovarsky district of the Republic of Bashkortostan, which is a subject of the Russian Federation. The study was carried out during March and April 2018. Blood analysis and inoculation of intestinal contents were carried out in the Department of Morphology, Pathology, Pharmacy, and Non-infectious Diseases of the Bashkir State Agrarian University.

Research objects. The objects of the study were broiler chickens of the "Ross 308 " cross. One hundred chickens aged 5 days were selected for the experiment according to the analogue pair principle, considering their appearance and body weight. The average weight of the birds was $118.5 \pm 1.5 \mathrm{~g}$. They were divided into 2 groups. Chickens in group 1 (control group) were fed the main diet. In group 2 (experimental group), chickens received Vitafort probiotic, including $B$. subtillis $11 \mathrm{~B}$ with water $\left(1 \times 10^{8} \mathrm{CFU} / \mathrm{ml}\right)$. Vitafort used for the experiment is manufactured by the research and development enterprise Biofort (Ufa, Russia). For the first five days (from day 5 to day 10), the chickens received Vitafort at a dose of $1 \mathrm{ml}$ per 50 heads (or $0.02 \mathrm{ml} /$ head) according to the manufacturer's recommendations. Then, the administration of the probiotic was discontinued until the birds were 28 days old. From the $28^{\text {th }}$ to the $32^{\text {nd }}$ day of life, the birds received Vitafort again according to the same scheme. The experiment lasted 6 weeks (42 days).

The birds of both groups were kept on a deep litter, according to the breeding technology. Birds from the experimental and control groups were kept in separate rooms in special areas. Birds from both groups were fed the same diet recommended for the Ross 308 cross by AllRussia Research and Engineering Poultry Institute. Raising 1 broiler chicken up to the age of 42 days requires $4.7 \mathrm{~kg}$ of feed.

Research methods. The following indicators were recorded: the poultry survival rate, live weight, average daily growth, blood morphological parameters, the number of Bacillus subtilis in the contents of the small intestine.
The live weight of broiler chickens of the experimental and control groups was determined by weighing each chicken every 7 days, starting from day 7 and ending on day 42. Electronic scales BE15TE, manufactured by Mass-K, St. Petersburg, Russia, were used for weighing; the measurement error is $\pm 0.2 \mathrm{~g}$.

Blood from 5 birds of each group was taken from the underwing vein for morphological analyses at the beginning and end of the experiment. An automatic blood analyzer Abacus junior Vet 5 was used to make the analysis.

The concentration of Bacillus subtilis was determined in the chickens 5 days after the beginning of the experiment. For this purpose, the contents of the small intestine were taken from 5 experimental chickens. The resulting material was diluted with saline solution at a concentration of $1: 10$. Then, material inoculation was performed for the quantitative determination of the Bacillus subtilis content. Incubation was carried out for 48 hours at a temperature of $33 \pm 2^{\circ} \mathrm{C}$, after which Bacillus subtilis colonies were recorded.

Statistical processing. The Student's criterion (t-test) was used to determine the statistical reliability. Due to the relatively small number of groups and a slight deviation of the variables from normal distributions, a nonparametric Kruskal-Wallis analysis of variance was performed using the licensed software package Statistica 10 (Tibco Software Inc., California, USA). The significance level was $p<0.05$.

Ethical statement. The authors declare that this paper was written with due consideration of ethical standards. The study was conducted in accordance with ethical principles approved by the Ethics Committee of Federal State Budgetary Educational Establishment of Higher Education "Bashkir State Agrarian University” (Protocol № 6 of 13.06.2020).

\section{Results and discussion}

Birds' growth and development throughout their lives depend on adequate nutrition, proper maintenance, and breeding technology. In the present study, a positive trend was noted in the live weight of chickens at all stages (Tab. 1). As shown in Tab. 1, the live weight of broiler chickens in the experimental group was significantly greater than it was in the control group in all age periods. The minimum difference was observed on day 28 , and it amounted to $1.44 \%$. The maximum difference, amounting to $4.21 \%$, was found on day 42. On day 42, the feed conversion ratios in the control group and experimental groups were 1.88 and 1.8 , respectively.

Tab. 1. Dynamics of broiler chickens' body weight (g)

\begin{tabular}{|l|c|c|}
\hline \multicolumn{1}{|c|}{ Age of chickens } & \multicolumn{2}{|c|}{ Live weight } \\
& Control & Experimental \\
\hline 7 days & $168 \pm 3.3$ & $175 \pm 2.9$ \\
14 days & $435 \pm 7.1$ & $445 \pm 6.1$ \\
\hline 21 days & $842 \pm 12$ & $862 \pm 10.3$ \\
28 days & $1360 \pm 19$ & $1380 \pm 17$ \\
\hline 35 days & $1940 \pm 26$ & $2001 \pm 25$ \\
42 days & $2500 \pm 26$ & $2610 \pm 27$ \\
\hline
\end{tabular}


Thus, it can be assumed that the use of the probiotic Vitafort has a stimulating effect on the body of broiler chickens from the first days of life. This is probably due to the normalization of the microflora of the gastrointestinal tract, which directly affects the weight and livability of birds.

Diet adequacy is directly related to the average daily increase, and any diet imbalance immediately reflects on this indicator.

The average daily weight gain is shown in Tab. 2 . As can be seen, the birds of the experimental group

Tab. 2. Average daily gain (g)

\begin{tabular}{|l|r|r|}
\hline \multicolumn{1}{|c|}{ Age of chickens } & \multicolumn{2}{c|}{ Average daily gain } \\
& Control & Experimental \\
\hline $0-7$ days & $38.14 \pm 0.3^{*}$ & $38.5 \pm 0.9$ \\
\hline 8-14 days & $58.1 \pm 0.1$ & $59.57 \pm 0.7$ \\
\hline $15-21$ days & $74 \pm 1.2$ & $74 \pm 1.3$ \\
\hline $22-28$ days & $82.85 \pm 0.8$ & $88.71 \pm 0.7$ \\
\hline $29-35$ days & $80 \pm 0.6$ & $87 \pm 0.5$ \\
36-42 days & $82.1 \pm 0.6$ & $86.6 \pm 0.7$ \\
\hline $0-21$ days & $39.8 \pm 0.6$ & $42.2 \pm 0.7$ \\
\hline $22-42$ days & $78.73 \pm 0.5^{*}$ & $83.46 \pm 0.65$ \\
Whole period & $56.5 \pm 0.45$ & $59.86 \pm 0.7$ \\
\hline
\end{tabular}

Explanation: $* \mathrm{p} \leq 0.05$.

Tab. 3. Some morphological parameters of chicken blood on day 42

\begin{tabular}{|l|c|c|}
\hline \multicolumn{1}{|c|}{ Indicators } & Control group & Experimental group \\
\hline Red blood cells, $10^{12} / l$ & $3.09 \pm 0.1$ & $3.31 \pm 0.3^{*}$ \\
\hline White blood cells, $10^{9} / l$ & $33.1 \pm 0.5$ & $33.8 \pm 0.66$ \\
\hline Haemoglobin, $\mathrm{g} / \mathrm{l}$ & $90.1 \pm 2.1$ & $93.31 \pm 2.3$ \\
\hline
\end{tabular}

Explanation: as in Tab. 2.

Tab. 4. Contents of the small intestine of chickens of the experimental group on day 5 of the experiment

\begin{tabular}{|c|l|l|l|c|c|c|}
\hline \multirow{2}{*}{$\begin{array}{c}\text { No } \\
\text { samples }\end{array}$} & \multirow{2}{*}{ Microorganisms } & \multicolumn{4}{|c|}{ Sample dilution } & \multirow{2}{*}{ CFU/g } \\
\hline 1 & B. subtilis & continuous & continuous & $35,47,40$ & $6,5,5$ & $7.8 \times 10^{-2}$ \\
\hline 2 & B. subtilis & continuous & continuous & $28,29,31$ & $3,2,4$ & $4.1 \times 10^{4}$ \\
3 & B. subtilis & continuous & continuous & $31,29,29$ & $5,4,4$ & $4.4 \times 10^{4}$ \\
4 & B. subtilis & continuous & continuous & $29,30,31$ & $3,3,3$ & $5.4 \times 10^{4}$ \\
\hline 5 & B. subtilis & continuous & continuous & $38,38,39$ & $4,4,5$ & $8.2 \times 10^{4}$ \\
\hline
\end{tabular}

Tab. 5. Contents of the small intestine of chickens of the experimental group on day 42

\begin{tabular}{|c|l|l|l|c|c|c|c|}
\hline \multirow{2}{*}{$\begin{array}{c}\text { No } \\
\text { samples }\end{array}$} & \multirow{2}{*}{ Microorganisms } & \multicolumn{5}{|c|}{ Sample dilution } & \multicolumn{1}{c|}{ CFU/g } \\
\hline 1 & B. subtilis & continuous & continuous & 50 & 21 & 9 & $7.8 \times 10^{-4}$ \\
2 & B. subtilis & continuous & continuous & 58 & 17 & 8 & $6.0 \times 10^{8}$ \\
3 & B. subtilis & continuous & continuous & 50 & 11 & 6 & $4.0 \times 10^{8}$ \\
4 & B. subtilis & continuous & continuous & 52 & 14 & 6 & $5.2 \times 10^{8}$ \\
5 & B. subtilis & continuous & continuous & 53 & 15 & 6 & $5.8 \times 10^{8}$ \\
\hline
\end{tabular}

had a higher average daily weight gain compared to the control group throughout the entire study period. The maximum average daily weight gain was recorded on day 35 of breeding. In the control group, it was $82.85 \mathrm{~g}$, and in the experimental group, $88.71 \mathrm{~g}$, which was $6.06 \%$ higher than in the control group. The livability of the birds of both groups was recorded throughout the entire course of the study. In the control group, it was $92 \%$, and in the experimental group, $95 \%$. The highest mortality rate in both groups was recorded from day 7 to day 14 .

Morphological blood parameters of broiler chickens of the experimental and control groups on day 5 after birth were within the physiological norm. No significant differences between them were recorded. According to Table 3, the concentration of red blood cells in the chickens of the experimental group on day 42 was $6.64 \%$ higher $(p \leq 0.05)$ than that in the control group. The amount of haemoglobin in the experimental group was $3.44 \%$ higher than that in the control group. Thus, the Vitafort probiotic may affect the physiological status of the bird's body. An increase in red blood cells and haemoglobin contributes to the improvement of metabolic processes because of an increase in the transport abilities of red blood cells. The table data show a slight increase $(2.11 \%)$ in the level of white blood cells in the broiler chickens of the experimental group due to an increase in nonspecific resistance.

To determine the content of Bacillus subtilis and undesirable microflora in the gastrointestinal tract of the birds of the experimental group, bacterial inoculation of the small intestine was carried out (Tab. 4, 5).

When analyzing Tab. 4, it was noted that colonies obtained from the contents of the small intestine of chickens of the experimental group were colorless, slightly convex, mostly oval or rounded, with a diameter of 2.2-4 mm. In 7-day-old chickens, the number of Bacillus subtilis varied from $4.1 \times 10^{4}$ to $8.2 \times 10^{4}$.

The results of inoculation of the contents of the small intestine of chickens at the age of 42 days (average values from 3 cups) are shown in Tab. 5.

Table 5 shows that colonies obtained from the contents of the small intestine on day 42 had similar characteristics: they were colorless, slightly convex, oval or rounded, with a $1.9-4 \mathrm{~mm}$ diameter. The number of Bacillus subtilis on day 42 varied from $4 \times 10^{8}$ to $5.8 \times 10^{8}$. Thus, the probiotic Vitafort may 
contribute to the normalization of the microflora of the gastrointestinal tract of broiler chickens.

Probiotics are living microorganisms that can be part of food products and certain medicines or independent probiotic preparations (additives). Strains of Lactobacterium $(21,24)$ and Bifidobacterium, Bacillus subtilis (12) are the most widespread. Probiotic drugs may consist of one or more strains. Probiotics containing multiple strains are more appealing since they are active against various conditions and can be used in different animal species (10).

The primary role of probiotics is to support the colonization resistance of the intestinal mucosa to opportunistic pathogens and reduce the risk of dysbiosis, which provokes and complicates gastrointestinal diseases in animals and birds (8). Probiotics have pronounced antagonistic properties against specific pathogens and pathogenic bacteria and the ability to produce antimicrobial and antibiotic substances (lactic acid, hydrogen peroxide, lysozyme, bacteriocins, etc.). Thus, they protect the gastrointestinal tract from inflammatory processes (39). The use of the Vitafor probiotic also affects the livability of the bird population. Thus, in the experimental group, its rate amounted to $95 \%$. Similar data were presented by Teo and Tan (37), who noted that $B$. subtilis PB6 helped maintain the number of beneficial bacteria and reduced the mortality rate of infected birds in groups treated with antibiotics and in groups treated with $B$. subtilis PB6 alone from 14\% to $6 \%$ and $8 \%$, respectively. In the course of the study, it was observed that the Vitafort probiotic promoted the colonization of broiler chickens' gastrointestinal tract by Bacillus subtilis and reduced the amount of pathogenic microflora. Medzhitov (23) obtained similar results. He noted that an increase in a particular genus or type of microbes leads to a decrease in the number of other microbes, which results in a change in the immune-interactive profile. The interactive coexistence of the immune system and microorganisms is particularly well observed in the intestinal tract, where gut-associated lymphoid tissue has evolved to provide optimal protection against intestinal pathogens (11). Fuller (10) emphasizes that the mechanism for preventing colonization by pathogenic microorganisms is competition for sites of adhesion to the surface of the intestinal epithelium. In this regard, when developing probiotic supplements, it is desirable to use adherent strains.

When studying the effect of the Vitafort probiotic on the body of broiler chickens, an increase was observed in the daily weight gain and live weight of birds in the experimental group. Vitafort improved the intestinal microflora. Thus, it may contribute to a better absorption of nutrients in the small intestine and their more productive use. Sandeepa and Ammani (31) also noted changes in the live weight of oysters after the use of lactobacilli. The use of lactobacilli at a concentration of $10 \%$ led to an improvement in growth performance, serum protein concentration, glucose, triglycerides, and shrimp health. According to Ovcharova, Petrakov et al. (27) and Blum and Schiffrin (5), probiotic effects in the body are not limited to the normalization of the intestinal microflora, but also include metabolic effects (positive influence on metabolic processes, normalization of the lipid profile, blood sugar levels, etc.) and immunological effects (improvement of humoral and cellular immunity, reduction of allergization of the body). In addition, probiotics also stimulate local immunoprotection, strengthen the mucous protective barrier, and reduce the severity of inflammation of the gastric mucosa. The analysis of the morphological blood parameters of broiler chickens receiving Vitafort revealed an increase in the level of white blood cells, which can be associated with an increase in nonspecific resistance of the body. Cheremushkina et al. (8), who used the probiotic Prolam, noted an increase in the number of activated neutrophils in the bloodstream and their increased absorption capacity. Microorganisms present in the Prolam probiotic are involved in forming intestinal biocenosis at the early stages of immune system development. They are primary antigens for native white blood cells and stimulate their proliferation and activation.

The probiotic Vitafort improves the intestinal microflora. Thus, it can be concluded that it contributes to a better absorption of nutrients in the small intestine and their more productive use. The broiler chickens of the control and experimental groups were fed the same diet. But a higher growth rate was observed in the experimental group, as shown by the average daily growth and live weight of birds. Thus, on day 42 the live weight of birds in the experimental group was $2610 \pm 27 \mathrm{~g}$, which was $4.21 \%$ higher than in the control group. On day 35 , the maximum average daily growth $(86.71 \mathrm{~g})$ was observed in the experimental group exceeding the control group by $6.06 \%$. The probiotic Vitafort improved intestinal microflora and increased feed conversion, resulting in the birds' weight gain.

\section{References}

1. Abudabos A. M., Al-Batshan H. A., Murshed M. A.: Effects of prebiotics and probiotics on the performance and bacterial colonization of broiler chickens. South Afr. J. Anim. Sci. 2015, 4, 419-428.

2. Afanasyev G. D., Erigina R. A., Razzak S. R. R.: Meat quality of egg cross cockerels. Poul. Poul. Prod. 2015, 1, 12-15.

3. Andersson H., Asp N. G., Bruce A., Roos S., Wadström T., Wold A. E.: Health effects of probiotics and prebiotics. A literature review on human studies. Näringsforskning 2001, 45, 58-75.

4. Anufrieva N. V., Lantseva N. N., Ryabukha L. A., Shvydkov A. N., Grevtsova A. E.: Prospects of using the beluga feed material in poultry breeding. Ann. Agri Bio Res. 2019, 24, 309-315.

5. Blum S., Schiffrin E.: Intestinal microflora and homeostasis of the mucosal immune response: implication for probiotic bacteria? Curr. Issues Intest. Microbiol. 2003, 4, 53-60.

6. Brylin A. P.: Effective probiotic in intensive poultry farming. Vet. Med. 2006, 10, 16-17.

7. Charyev A. B.: Selection, technological methods and techniques of effective production of broiler meat. Doctoral dissertation, Ufa, 2017. 
8. Cheremushkina I. V., Shakhov A. G., Sashnina L. Y., Chernitsky A. E., Yerina T. A.: Antagonistic activity of a probiotic Prolam in point of bacterial pathogens and its influence on an intestines microbiocenosis, the immune and clinical status of calfs. J. Anim. Vet. Adv. 2015, 14, 182-191.

9. Cherepanova N. G., Prosekova E. A., Panina E. V., Panov V. P., Semak A. E., Sidorova M. V., Kontsevova A. A.: Histology of the intestinal wall of broiler chickens when using various dietary supplements. Rev. Timiriazev Agric. Acad. 2019, 1, 98-112.

10. Fuller R.: Probiotics in man and animals. A review. J. Appl. Bacteriol. 1989 $66,365-378$

11. Gaboriau-Routhiau V., Rakotobe S., Lécuyer E., Mulder I., Lan A., Bridonneau C., Rochet V., Pisi A., De Paepe M., Brandi G., Eberl G., Snel J., Kelly D., Cerf-Bensussan N.: The key role of segmented filamentous bacteria in the coordinated maturation of gut helper T cell responses. Immunity 2009 31, 677-689.

12. Ganieva R. F., Fairushin R. N.: Ultrastructural characteristics of the intestinal nervous plexus of sheep with paramphistomosis when using Panakur and Vitafort. Morphol. 2018, 153, 71 .

13. Guarner F., Khan A. G., Garisch J., Eliakim R., Gangl A., Thomson A., Krabshuis J., Le Mair T.: Probiotics and prebotics. World Gastroenterol. Organisation Pract. Guideline, 2008. https://www.worldgastroenterology.org/ UserFiles/file/guidelines/probiotics-russian-2008.pdf

14. Hadad Y., Yaron Y., Druyan S., Cahaner A.: Early physiological and ascites susceptible broilers, [in:] XXII World's Poultry Congress; 8-13 June 2004, Istanbul-Turkey 2004, p. 119.

15. Holmes C.: USA researchers find genes making hen thin. Poultry Times 1984

16. Kalaeva E., Kalaev V., Efimova K., Chernitskiy A., Safonov V.: Protein metabolic changes and nucleolus organizer regions activity in the lymphocytes of neonatal calves during the development of respiratory diseases. Vet. World 2019, 12, 1657-1667.

17. Khasanov E. R., Khamaletdinov R. R., Mudarisov S. G., Shirokov D. Y, Akhunov R. Z.: Optimization parameters of the spiral mixing chamber of the device for pre-sowing seed treatment with biological preparations. Comput. Electron. Agric. 2020, 173, 105437.

18. Klaenhammer T. R., Kleerebezem M., Kopp M. V., Rescigno M.: The impact of probiotics and prebiotics on the immune system. Nat. Rev. Immunol. 2012 $12,728-734$

19. Lammers K. M., Helwig U., Swennen E., Rizzello F., Venturi A., Caramelli E., Kamm M. A., Brigidi P., Gionchett P., Campieri M.: Effect of probiotic strains on interleukin 8 production by HT29/19A cells. Am. J. Gastroenterol. 2002, 97, 1182-1186.

20. Levakhin V. I., Lasygina Y. A., Kharlamov A. V., Voroshilova L. N.: Probiotics in animal husbandry. Bull. Meat Cattle Breed. 2013, 1, 7-10.

21. Lomax A. R., Calder P. C.: Prebiotics, immune function, infection and inflammation: a review of the evidence. Br. J. Nutr. 2009, 101, 633-658.

22. Maldonado N. C., de Ruiz C. S., Otero M. C., Sesma F., Nader-Macías M. E. Lactic acid bacteria isolated from young calves - characterization and potential as probiotics. Res. Vet. Sci. 2012, 92, 342-349.

23. Medzhitov R.: Recognition of microorganisms and activation of the immune response. Nature 2007, 449, 819-826.

24. Miroshnikov S. A., Yausheva E. V., Sizova E. A., Miroshnikova E. P., Levahin V. I.: Comparative assessment of effect of copper nano- and microparticles in chicken. Orient. J. Chem. 2015, 31, 2327-2336.

25. Nikulin V. N., Kotkova T. V., Lukianov E. A., Milovanova E. A.: Efficiency of the use of probiotic lactobacilli in the feeding of agricultural poultry. Achiev. Sci. Technol. Agro-Industrial Complex 2014, 5, 38-40.

26. Nozdrin G. A., Ivanova A. B., Nozdrin A. G.: Bacillus subtilis based probiotics and their role in maintaining the health of animals of different species. Siberian Bull. Agric. Sci. 2007, 7, 64-68.

27. Ovcharova A. N., Petrakov E. S.: New proniotic specimens based on lactobacillus reuteri and prospects of their use in animal breeding. Issues Biol. Reprod. Anim. 2018, 2, 5-18

28. Parker R.: Probiotics, the other half of the antibiotic story. Anim. Nutr. Health 2014, 29, 4-8

29. Roberfroid M., Gibson G. R., Hoyles L., McCartney A. L., Rastall R., Rowland I., Wolvers D., Watzl B., Szajewska H., Stahl B., Guarner F., Respondek F., Whelan K., Coxam V., Davicco M. J., Léotoing L., Wittrant Y., Delzenne N. M., Cani P. D., Neyrinck A. M., Meheust A.: Prebiotic effects: metabolic and health benefits. Br. J. Nutr. 2010, 104, 1-63.

30. Salakhov F. D.: Blood composition of imported Holstein cows against the background of adaptation to new ecological and climatic conditions. Morphol. 2018, 153, 243.

31. Sandeepa M. G., Ammani K.: Effect of probiotic bacterium on growth and biochemical parameters of shrimp Litopenaeus vannamei. Int. J. Recent Sci. Res. 2015, 6, 2871-2875.
32. Shakirova G. R., Bolshunov V. A., Shakirova S. M.: Ultrastructure of the Coturnix quadriceps femora. Issues Regul. Legal Regul. Vet. Med. 2019, 2 131-134.

33. Shakirova G. R., Borkhunova E. N., Kondratov G. V., Stepanishin V. V.: Comparative characteristics of myohistogenesis of musculoskeletal tissue in hens and quails, [in:] E3S Web of Conferences (Vol. 254), EDP Sciences 2021, p. 09020.

34. Sorensen P.: Genetic aspects of skeletal disorders in poultry, [in:] XXII World's Poultry Congress; 8-13 June 2004, Istanbul, Turkey 2004, p. 115.

35. Sukhanova S. F. Azaubaieva G. S.: The use of preparations of the Vetom series in mixed feeds of young geese. Poult. Farm. 2014, 10, 25-27.

36. Sultanova R. R., Gabitov I. I., Yanbaev Y. A., Yumaguzhin F. G., Martynova M. V., Chudov I. V., Tuktarov V. R.: Forest melliferous resources as a sustainable development factor of beekeeping. Isr. J. Ecol. Evol. 2019, 65, 77-84.

37. Teo A. Y. L., Tan H. M.: Effect of Bacillus subtilis PB6 (CLOSTAT) on broilers infected with a pathogenic strain of Escherichia coli. J. Appl. Poult. Res. 2006, 15, 229-235

38. Usova T. V., Lantseva N. N., Shvydkov A. N., Ryabukha L. A., Shmakova S. V. Prospects of using a feed additive from the biological feed complex (bfc) in poultry breeding. Ecol. Environ. Conserv. 2018, 24, 477-483.

39. Viera A. T., Teixereira M. M., Martins F. S.: The role of probiotics and prebiotics in inducing gut immunity. Front. Immunol. 2013, 445, 1-12.

40. Yang N.: Breeding for specific consumers preference of chickens, [in:] XXII World's Poultry Congress; 8-13 June 2004, Istambul, Turkey 2004, p. 143

41. Yirga H.: The use of probiotics in animal nutrition. J. Probiotics Health 2015, 3, 1000132 .

Corresponding author: Rifkat Fairushin, PhD, Associate Professor, Department of Morphology, Pathology, Pharmacy and Non-Infectious Diseases, Federal State Budgetary Educational Establishment of Higher Education "Bashkir State Agrarian University", 50-letia Octyabrya str., 34, Ufa, 450001, Russian Federation; e-mail: rifairushin@rambler.ru 